Research.

\title{
THE EFFECT OF CAPITAL EXPENDITURE AND INVESTMENT ON INCOME INEQUALITY
}

\author{
Jouzar Farouq Ishak ${ }^{1}$, \\ Amelia Rizky Alamanda², \\ R. Wedi Rusmawan Kusumah ${ }^{3}$ \\ ${ }^{1}$ Politeknik Negeri Bandung, Indonesia \\ ${ }^{2}$ Universitas Padjajaran. Bandung, Indonesia \\ ${ }^{3}$ Universitas Widyatama. Bandung, Indonesia
}

Received: January 30, 2018; Accepted: April 19, 2018; Published: June 30, 2018

To cite this article: Jouzar Farouq Ishak, Amelia Rizky Alamanda, and R. Wedi Rusmawan Kusumah, The Effect of Capital Expenditure and Investment on Income Inequality, The Accounting Journal of BINANIAGA, Vol. 03, No. 01, June 2018, pp. 51 - 58.

Abstract. The purpose of this study to give empirical evidence and examines the influence of capital expenditure and investment on income inequality at The Special Administrative Region of Yogyakarta. The research objects are The Special Administrative Region of Yogyakarta by considering pooled data and the sampling design as purposive sampling. The sampling here is confined to specific types of people who can provide the desired information, either because they are the only ones who have it, or conform to some criteria set by the researcher. This analysis uses multiple regression analysis is a statistical technique to predict the variance in the dependent variable by regressing the independent variables against it. The result of research shows that capital expenditure has no significant influence on income inequality in The Special Administrative Region of Yogyakarta, Investment has a significant influence on income inequality in The Special Administrative Region of Yogyakarta, capital expenditure and investment simultaneously significant influence on income inequality in The Special Administrative Region of Yogyakarta.

Keywords: capital expenditure, investment, income inequality

\section{INTRODUCTION}

Initial idea about development is often associated with progress, or development with modernization focusing on four central issues: (a) capital accumulation (b) economic growth (c) governmental role and (d) structural transformation. Based on the paradigm has led many developing countries to enter the more modern stage as a starting point toward a more prosperous life. Nevertheless, still reap a lot of criticism because it has created a gap and imbalance. This situation generates criticism by focusing on four basic issues: (1) high poverty, (2) unequal income distribution, (3) injustice, and (4) lack of freedom in democracy. According to this paradigm the meaning of development is not solely on the increase of per capita income, but the decrease of unemployment and poverty, equitable distribution of income, and the elimination of injustice (Sabir, 2015).

The success of an economic development can't be measured only from an aggregate or per capita growth rate of output or an increase in income. But, even more important, it must be seen also from the distribution pattern of the increase in income (Tambunan, 2011).

The importance of the role of human capital in development is seen in the attention of various parties such as government and private sector that allocate investment and 
local expenditure to improve the quality of human capital. Indeed, the investment allocated for the benefit of this human capital does not necessarily can be seen the results in a short time. So it is not surprising that within the government budget there is often a trade-off between investment in economic infrastructure (physical) and investment for the human capital development sector (Sjafii, 2009).

Investment can be a starting point for the success and sustainability of future development because it can absorb labor, so it can open up new job opportunities for the community which in turn will have an impact on the increase of people's incomes (Wahyuni, Sukarsa, \& Yuliarmi, 2014).

Approaches that are considered appropriate as with other developing countries are the decentralized approach of development, replacing the centralized approach of development. Through the decentralization policy of regional development, it is expected that the implementation of development program will be more effective in encouraging the improvement of community welfare (Sabir, 2015).

A more prosperous life is criticized for having created an imbalance in the unfair distribution of income. The Special Administrative Region of Yogyakarta is the province with the highest levels of income inequality in Indonesia by the year 2016. The following table 1 is the province with the highest income disparities in Indonesia:

Table 1. Gini Coefficient

\begin{tabular}{|c|l|c|}
\hline No. & \multicolumn{1}{|c|}{ Province } & Gini Coefficient \\
\hline 1 & DI Yogyakarta & 0,4225 \\
\hline 2 & Gorontalo & 0,4145 \\
\hline 3 & Sulawesi Selatan & 0,4130 \\
\hline 4 & Jawa Barat & 0,4075 \\
\hline 5 & Jawa Timur & 0,402 \\
\hline
\end{tabular}

Source: Statistics Indonesia

\section{LITERATURE REVIEW}

Freeman et al. (2014) suggest that the primary measurement focus on governmental funds is on currently expendable net financial assets and changes in currently expendable net financial assets. Therefore, activities financed through governmental funds are usually planned, authorized, controlled, and evaluated in terms of expenditures - the primary outflow measurement in governmental fund accounting. Expenditures, a different measurement concept than expenses, is a measure of fund liabilities incurred (or expendable fund financial resources used) during a period for operations, capital outlay, and debt service. Expenses indicate the measure of costs expired or consumed during a period.

Under the modified accrual basis of accounting, governmental funds are concerned with expenditures. By contrast, proprietary funds, like businesses, focus on expenses. Expenditures are narrower in scope than expenses. Whereas expenditures are decreases in net financial resources, expenses are decreases in net economic resources. Expenditures are generally recognized when an asset is acquired; expenses when it is consumed (Granof and Khumawala, 2011).

Bastian (2011) define Government expenditures in order to fund the implementation of Government Affairs, which became the Provincial authority or 
district/city that consists of a mandatory affairs are handled in parts or specific areas that can be implemented jointly between the Government and the local governments or intergovernmental areas defined by the provisions of the legislation. Conducting the Affairs of the mandatory spending is prioritized to protect and improve the quality of life of the community in an attempt to meet the obligations of the region is manifested in the form of increased basic services, education, health, social facilities, and a decent public facilities as well as developing a social security system.

Investments Government made in the form of Investment Securities and Direct Investment. Investment Securities include investments by way of purchase of shares and bonds. While direct investment includes equity capital and or loan (Republik Indonesia, 2008). Principle investment government is:

1. The principle of Functional that decision making and problem solving in the field of Government Investment was implemented by the Minister of finance, Government Investment Agencies, business entities, the Technical Secretary or institution of appropriate functions, authority, and responsibility each;

2. The principle of Legal Certainty that Government Investment should be implemented based on laws and regulations that apply;

3. The principle of Efficiency that Government Investment is directed so that the investment funds used according to standard limitations needs required in order to support the Organization of basic tasks and functions of Government optimally;

4. The principle of Accountability, namely any investment activity the Government should be accountable to the people with a sense of Justice and propriety, and the last;

5. The principle of Certainty of Value, namely Government Investment must be supported by the precision of the number and value of investments in order to optimize the utilization of funds and Divestment as well as the preparation of the financial statements of the Government.

Investments according to Granof and Khumawala (2011) are of concern because of the substantial risk that can incur - losses through default, declines in value, and even fraud. The concerns of governments, not-for- profits, and their constituents with regard to investment extend beyond issues of accounting. Investment in marketable securities and related financial instruments, such as commodity options, allow organizations to enhance revenues and, in some cases, to better manage their risks. But they also present special hazards. Many governments invest their funds directly in stocks, bonds, notes, and other financial instruments.

Bastian (2011) report that in doing investments without mistakes, it has to do a feasibility study and calculations of future cash flows. The Fund used to invest must be ascertained in advance that these funds of funds that is completely idle (idle cash). The basis of valuation of investments noted in the balance sheet should be noted clearly. If there is a long-term investment that pawned should be accompanied by explanations and methods used in the calculation of long-term investment should be disclosed in the financial statements.

Another source of differences in wages is discrimination. Discrimination occurs when the marketplace offers different opportunities to similar individuals who differ only by race, ethnic group, sex, age or other personal characteristics. Discrimination reflects some people's prejudice against certain groups in society. Although discrimination is an emotionally charged topic that often generates heated debate, economists try to study the topic objectively in order to separate myth from reality (Mankiw and Taylor, 2010).

Gini coefficients are drawn from the Standardized World Income Inequality Database and are based on incomes before taxes and transfers. Real gross domestic product growth rates, total public spending, and the individual spending items are derived from data drawn from the World Development Indicators. The model is estimated separately for each individual expenditure item (Asian Development Bank, 2014).

Jouzar Farouq Ishak, Amelia Rizky Alamanda, and R. Wedi Rusmawan Kusumah:

The Effect of Capital Expenditure and Investment on Income Inequality 
Based on Mankiw and Taylor (2010) although the profit motive is a strong force acting to eliminate discriminatory wage differentials, there are limits to its corrective abilities. Here we consider one of the most important limits is government policies. Another way for discrimination to persist in competitive markets is for the government to mandate discriminatory practices.

(Kasipmabin, Setiawina, \& Purbadharmaja, 2016) found that government expenditure has direct influence against inequality income distribution. The attention of local governments should not only increase the budget, but also the budget allocation especially for refinements health and community empowerment because healthy human also specify social welfare area concerned.

According to (World Economic Forum, 2014) the public and private sectors can work together to foster lending and investment with long-term perspective. The insurance industry can play a central role in risk mitigation for entrepreneurs and collectives, but governments and international institutions have to facilitate intergenerational asset transfer as well. Only fair and sustainable systems of tax and subsidy redistribution will ensure growth that also encompasses social protection, remedies poverty and allows for resource-friendly and environmentally sound development.

(Wahyuni et al., 2014) in his research even suggested investment is positive and significant effect against the inequalities of income. This means that increased investment income gap will then increase. In an area that is undergoing development, rising demand will boost income and demand, which further raise investment.

\section{RESEARCH METHODOLOGY}

The objective of a descriptive study is to describe. Descriptive studies are often designed to collect data that describe the characteristics of persons, events, or situations (Sekaran and Bougie, 2013). It may involve the collection of secondary data for this research such as capital expenditure, investment and gini coefficient data from Statistics Indonesia and other documents published by The Government. Secondary data means data that are already, that is they refer to the data which have already been collected and analyzed by someone else. When the researcher utilizes secondary data, then he has to look into various sources from where he can obtain them. In this case he is certainly not confronted with the problems that are usually associated with the collection of original data (Kothari and Garg 2014).

The population refers to the entire group of people, events, or things of interest that the researcher wishes to investigate. It is the group people, events, or things of interest for which the researcher wants to make inferences. A sample is a subset of the population. It comprises some members selected from it. In other words, some, but not all, elements of the population form the sample (Sekaran and Bougie, 2013).

Non-probability sampling is that sampling procedure which does not afford any basis for estimating the probability that each item in the population has of being included the sample. In this type of sampling, items for the sample are selected deliberately by the researcher; his choice concerning the items remain supreme (Kothari and Garg, 2014).

This research was conducted in The Special Administrative Region of Yogyakarta years 2007 up to the year 2014. The selection of The Special Administrative Region of Yogyakarta because due to the gini coefficient in The Special Administrative Region of Yogyakarta is larger than other provinces in Indonesia. In addition, the enactment of regulation of The Minister of Home Affairs in 2007 about Expenditures into basic election data starting from the year 2007. 


\section{DISCUSSION AND INTERPRETATION}

The magnitude of the influence of variables $X_{1}$ and $X_{2}$ against $Y$ is shown in the table 2 below:

Table 2. Table Coefficients

Coefficients

\begin{tabular}{|c|c|c|c|c|c|c|}
\hline \multirow[b]{2}{*}{ Mod } & & \multicolumn{2}{|c|}{$\begin{array}{c}\text { Unstandardized } \\
\text { Coefficients }\end{array}$} & \multirow{2}{*}{$\begin{array}{c}\text { Standardized } \\
\text { Coefficients }\end{array}$} & \multirow[b]{2}{*}{$\mathrm{t}$} & \multirow[b]{2}{*}{ Sig. } \\
\hline & & B & Std. Error & & & \\
\hline \multirow[t]{3}{*}{1} & (Constant) & .343 & .018 & & 18.883 & .000 \\
\hline & Belanja Modal & $8.41 \mathrm{E}-015$ & .000 & .072 & .279 & .788 \\
\hline & Investasi & 1.02E-014 & .000 & .783 & 3.021 & .019 \\
\hline
\end{tabular}

a. Dependent Variable: Kesenjangan Pendapatan

Based on table 2 that capital expenditure has no effect against income inequality. This means the higher capital expenditures then income inequality can be decline. International experience shows that public spending can reduce income inequality. Government spending on education and health care, for example, broadens access for the poor to these vital services and levels the playing field (Asian Development Bank, 2014).

This research is different from research conducted by (Kasipmabin et. al., 2016) found that government expenditure has direct influence against inequality income distribution. Public spending on education and health in particular seem to offer a lot of scope for reducing inequality. Using a data set covering both advanced and developing economies find that aggregate government expenditures on social welfare, education, health, and housing significantly reduce income inequality over time (Asian Development Bank, 2014).

Based on table 2 that investment has effect against income inequality. Returns to human capital are largely driven by the market, and it may not be efficient and or even desirable for governments to try to alter them. However, it is efficient and desirable for governments to reduce inequality in the distribution of human capital in the population, by making public investments in education and health and by ensuring that all members of society have equal access to these basic services, regardless of their individual circumstances (Asian Development Bank, 2012).

More investment should be put to further study this phenomenon and quantify it in terms of lost economic and social opportunities. With technological innovation creating new opportunities for social inclusion and civic empowerment, time is ripe for all actors to come together and enable an open civic space by collectively taking measures and engaging technology to address this risk effectively (World Economic Forum, 2017).

What is found this study is consistent and same with what is said by (Wahyuni et. al., 2014) in his research even suggested investment is positive and significant effect against the inequalities of income. With tight public finances, governments and regulators are having to devise mechanisms for leveraging private finance while seeking to avoid the inflexibility and questions over value for money that have dogged public-private infrastructure finance in the past. It is still unclear how the enormous investment needs for some kinds of infrastructure are going to be met (World Economic Forum, 2017).

Jouzar Farouq Ishak, Amelia Rizky Alamanda, and R. Wedi Rusmawan Kusumah:

The Effect of Capital Expenditure and Investment on Income Inequality 


\section{CONCLUSION AND SUGGESTION}

The conclusion of this research based on previous research is:

1. Capital expenditure has no significant influence on income inequality in The Special Administrative Region of Yogyakarta.

2. Investment has a significant influence on income inequality in The Special Administrative Region of Yogyakarta.

3. Capital expenditure and investment simultaneously significant influence on income inequality in The Special Administrative Region of Yogyakarta.

In addition, the authors give advice that the sample used in this study is limited to on The Special Administrative Region of Yogyakarta so generalizing the results of research and discussion of less enforceable for the other provinces in Indonesia. Expected to research that will it comes to be able to expand as well as add a sample research with a longer observation period in order to produce data that is more comprehensive and accurate.

\section{REFERENCES}

Asian Development Bank. (2012). Asian development outlook 2012, confronting rising inequality in asia. Asian development outlook. Retrieved from http://scholar.google.com/scholar?hl=en\&btnG=Search\&q=intitle:Confronting+Rising +Inequality+in+Asia\#0

Asian Development Bank. (2014). Asian development outlook 2014. Fiscal Policy for Inclusive Growth.

Bastian, I. 2011. Sistem akuntansi sektor publik (edisi kedua). Jakarta: Salemba Empat.

Freeman, R., J., et. al. 2014. Governmental and nonprofit accounting (tenth edition). Essex: Pearson Education Limited.

Granof, M., H., and Khumawala, S., B. 2011. Government and not-for-profit accounting: concepts and practices (fifth edition). New Jersey: John Wiley \& Sons Ltd.

Kasipmabin, L. L., Setiawina, N. D., \& Purbadharmaja, I. B. P. (2016). Pengaruh belanja pembangunan terhadap ketimpangan distribusi pendapatan dan kesejahteraan masyarakat. E-Journal Ekonomi Dan Bisnis Universitas Udayana: Bali, 5(5). Retrieved from https://ojs.unud.ac.id/index.php/EEB/article/view/8213/13897

Kothari, C., R., and Garg, G. 2014. Research methodology methods and technique (third edition). New Delhi: New Age International Publishers Limited.

Republik Indonesia. (2008). Peraturan Pemerintah Republik Indonesia Nomor 1 Tahun 2008 tentang Investasi Pemerintah.

Sabir. (2015). Pengaruh alokasi belanja modal terhadap pertumbuhan ekonomi, ketimpangan pendapatan, penyerapan tenaga kerja dan kesejahteraan masyarakat. Universitas Brawijaya.

Sekaran, U., and Bougie, R. 2013. Research methods for business (sixth edition). West Sussex: John Wiley \& Sons Ltd.

Sjafii, A. (2009). Pengaruh investasi fisik dan investasi pembangunan manusia terhadap

Jouzar Farouq Ishak, Amelia Rizky Alamanda, and R. Wedi Rusmawan Kusumah: The Effect of Capital Expenditure and Investment on Income Inequality 
pertumbuhan ekonomi Jawa Timur 1990-2004. Journal of Indonesian Applied Economics, 3(1), 59-76. https://doi.org/10.21776/ub.jiae.2009.003.01.3

Tambunan, T. (2011). Perekonomian Indonesia. Jakarta: Penerbit Ghalia.

Wahyuni, I. G. A. P., Sukarsa, M., dan Yuliarmi, N. (2014). Fakultas Ekonomi dan Bisnis Universitas Udayana, Bali , Indonesia. E-Journal Ekonomi Dan Bisnis Universitas Udayana: Bali, 3(8), 791-805. Retrieved from https://ojs.unud.ac.id/index.php/EEB/article/view/8216/7299

World Economic Forum. (2014). The global competitiveness report. World Economic Forum Reports 2014. https://doi.org/ISBN-13: 978-92-95044-73-9

World Economic Forum. (2017). The global competitiveness report. (Vol. 5). https://doi.org/92-95044-35-5 
The Accounting Journal of BINANIAGA Vol. 03, No. 01, June 2018

PISSN: $2527-4309$

EISSN: $2580-1481$

This page intentionally be emptied.

Jouzar Farouq Ishak, Amelia Rizky Alamanda, and R. Wedi Rusmawan Kusumah:

The Effect of Capital Expenditure and Investment on Income Inequality

Page : 58 